\title{
Teaching English Professional Writing in an E-learning Environment: An Italian Case Study
}

\author{
Anna Romagnuolo \\ Department of Economics and Management, Università Della Tuscia, Viterbo, Italy \\ Email address: \\ romagnuolo@unitus.it

\section{To cite this article:} \\ Anna Romagnuolo. Teaching English Professional Writing in an E-learning Environment: An Italian Case Study. International Journal of \\ Language and Linguistics. Vol. 3, No. 6, 2015, pp. 383-393. doi: 10.11648/j.ij11.20150306.21
}

\begin{abstract}
This paper will report on the author's four-year experience of teaching English for International Organizations and Their Discourse, a course especially developed for the distance learning Master program in Comunicazione nelle Organizzazioni e Imprese Internazionali (Communication in International Organizations and Enterprises) launched by the Linguistic Center of the University of La Tuscia, in Viterbo, Italy, in 2008, and the teaching of a Business Communication course, focused on business writing, initially offered as an elective and subsequently transformed into a core (blended-format) course in the graduate program of Marketing and Quality at the same University. The specific features, aims and target of the two courses will be briefly explained and followed by the discussion of the program development and results obtained.
\end{abstract}

Keywords: ESP, E-learning, Moodle, Writing Skills Development, Error Analysis

\section{Introduction}

Teaching online means conducting a course in a virtual learning environment which allows both synchronous elearning, with real time learner-instructor interaction, and asynchronous, self-paced e-learning through online platforms, mainly used as "slots" for posting lectures, PowerPoint presentations, videos, assignments, quizzes and grades - resources which can also complement, rather than replace, classroom-delivered content, creating hybrid or "blended" instruction. However, as Susanmarie Harrington, Rebecca Rickly and Michael Day observed in the introduction to their book, of the four language skills, "Teaching online privileges writing in ways that traditional classes cannot" [1] because most of the communication in an online classroom occurs through writing both between student and teacher and between students and because, being the meaning of communication mostly negotiated through writing, students are forced to pay more attention to the quality of their language outputs [2]. Moreover, in a distance learning environment, students are less anxious about their (foreign) language performance [3] and are encouraged to become language users as well as language learners [4]. Of course, learning outcomes do not only depend on students' engagement but also, and above all, on the course design and the alignment of the course objectives with those outcomes.

This paper will indeed discuss the design and the outcomes of two ESP courses, English for International Organizations and Their Discourse and Business Communication, targeting Italian graduate students and aiming at the development of professional writing skills. The first one, a two-semester course, was taught entirely online for two years and also offered as a blended learning option in its third edition. It was then put on hold due to a recent faculty restructuring program. In its hybrid version, onsite lessons were only devoted to role play activities and discussion of the reading material to be used for online assignments. The second course, Business Communication, a single-term course, has been offered in a blended format from the outset; therefore, its webpage does not only contain the required online writing assignments but also PowerPoint slides, lecture material and mock exam tests used in the classroom, which are yearly updated and uploaded for students to review. It was an elective module for the Master students and has been a compulsory course of the Marketing graduate program since 2011.

The organization and management of these two courses has implied selecting suitable theoretical frames and adjusting correction and evaluation methods to individual and group activities conducted on Moodle, which will also be summarized in this work. 


\section{Methodology}

This is a multiple-case study; therefore, observations and remarks are the result of the exploration of a "bounded system" [5], or a "case" built over time through the collection of similar cases or data (students' homework and exam tests) studied jointly to investigate the same phenomena: foreign language acquisition and writing skill development through online learning.

Data shown in Table 1 are the results of the comparison of aggregated test marks given to online Master students (a total of 252) attending the course of English for International Organizations and Their Discourse in the years 2008-2011; data shown in Table 2 are the result of the comparison of individual performance over the same assignments submitted by 124 students of the Business Communication online course of this academic year (2014-2015).

\section{Course Description}

\subsection{Course Rationale and Assumptions}

The course of English for International Organizations and Their Discourse (Eng4Int.Orgs) addressed the English language needs of people who were training for or had already started a career in the fields of international relations, international organizations or international trade. It was, therefore, designed for adult foreign/second language learners with an intermediate or advanced level of proficiency in English. Professional terminology and textual genres specific to the jobs and relevant to the core disciplines involved in the Master (International Law, International Politics, and Human Rights) were emphasized throughout the four modules of the English course (International Legal English and Commercial Law; Intergovernmental Organizations; Non-governmental Organizations; Human Rights Protection), which were also complemented by the optional module in Business Communication (Bus.Com).

With the exception of few language courses and textbooks aiming at teaching English skills to international lawyers, and few reading texts and vocabulary building manuals for Political Science students, so far ESP and EOP courses have not yet devoted considerable attention to the specific variety of English used in IRs and by IOs. Thus, in 2008, when it was launched, the Italian University 12-month Master program and its course of English for International Organizations were quite innovative.

The implied claim of this course was that international relations and global corporations have developed specific strategies and language(s) by which they legitimate and pursue their goals. Given the interplay of politics and economics, the growing interdependence between countries and the increasing cultural homogenization resulting from rapid travel and communications, the list of International Organizations which the course reading material took into account included many more (inter)national actors than the $\mathrm{UN}$ and other well-known intergovernmental organizations (IGOs): it also included transnational actors (NGOs and
MNCs) and other actors exerting worldwide economic and political power such as trade organizations and global cable networks, such as CNN and BBC World, which can influence public opinion.

All these international actors use English as a lingua franca for several purposes and in different activities, ranging from identity-building (mission statements, diplomatic documents, etc.) to legitimacy construction (foreign policy studies, theory articles), from auto-regulation (resulting in legal instruments such as treaties, conventions, international agreements, internal rules and regulations) to the enforcement of international law (implementation of international control systems such as UN resolutions, peacekeeping operations, authorized military actions, economic and diplomatic sanctions, judicial decisions, etc.), from administrative and bureaucratic duties (such as letter, memo, report writing, etc.) to activism and campaign organization (peace-building training, NGOs' mobilization, etc.). Therefore, individuals aiming at working for or with an international actor need to be familiar with the language variety used in that professional environment and able to use its conventionalized and situationally relevant forms of communication [6-8]. Thus, the course fundamental objective was to develop this familiarity.

The course of Business Communication has aimed at developing students' business and administrative writing skills in English by teaching business communication theory and etiquette and practicing the basic forms of business correspondence (enquiries, replies, orders, complaints, apologies, fundraising and application letters, memos, reports). It is intended for students who have already developed and shown a pre-intermediate language competence in English by passing the undergraduate English language exam or by getting intermediate language certifications (B1 or above). While stressing the importance of reader-oriented attitude, cross-cultural politeness and pragmatic competence in practical writing assignments, the course has also illustrated (through reading material) the development of business communication principles with an overview of the history of the discipline from medieval Ars Dictaminis and Mercatoria to 16th C. epistolary theory, from 19th century letter-writing instruction to modern managerial and organizational communication guidelines.

The assumptions underlying both course designs are: 1) the ability to apply the knowledge of a foreign language to practical communicative activities such as listening, speaking, reading and, above all, writing in a specific professional context requires an understanding of the professional sector and some knowledge of the subject field(s) - theoretical grounds, scope, purpose, and discourse practices - upon which that profession is based; 2) online foreign language courses whose development mostly relies on written CMC forms and asynchronous learning tools are better tailored to meet students' specialist vocabulary needs (by employing both traditional pre-loaded drills, fill-in, and drag-and drop exercises and more recent CALL applications such as corpora and concordancers) and to develop reading, 
listening and especially writing (more than oral) skills by using CMS software allowing teachers to monitor and track student participation and assignment completion.

Both online and blended courses have relied on a type of CMS called Moodle.

\subsection{Course Management System}

First released in 2002 and now freely available in version 2.9, Moodle (Modular Object-Oriented Dynamic Learning
Environment) is an open source web-based learning management system working in any modern web browser, and used by educational institutions all over the world - as of July 2015, 56,575,331 users all over the world and 5,998,693 registered courses [9]. By default, a Moodle course has a three-column layout with the side columns consisting of blocks with course settings and information, and the center column containing the course content (see Fig.1).

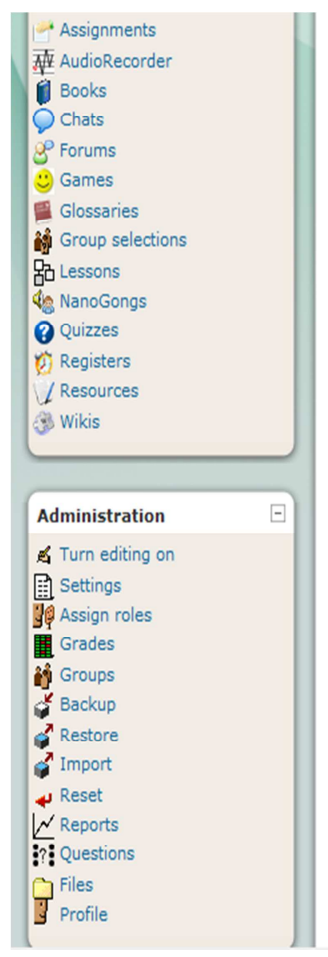

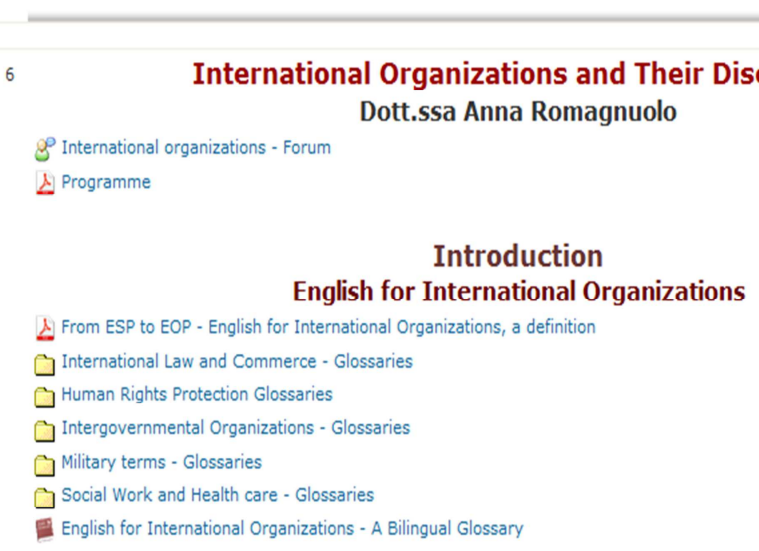

Module 1 International Legal English

$\checkmark$ Web resources

INTERNATIONAL LEGAL ENGLISH

$$
\begin{aligned}
& \qquad \text { Legal English - An introduction } \\
& (2 \text { Reading: International Law } \\
& \text { Listening International Legal English } \\
& \text { ? International law: Check your vocabulary knowledge }
\end{aligned}
$$
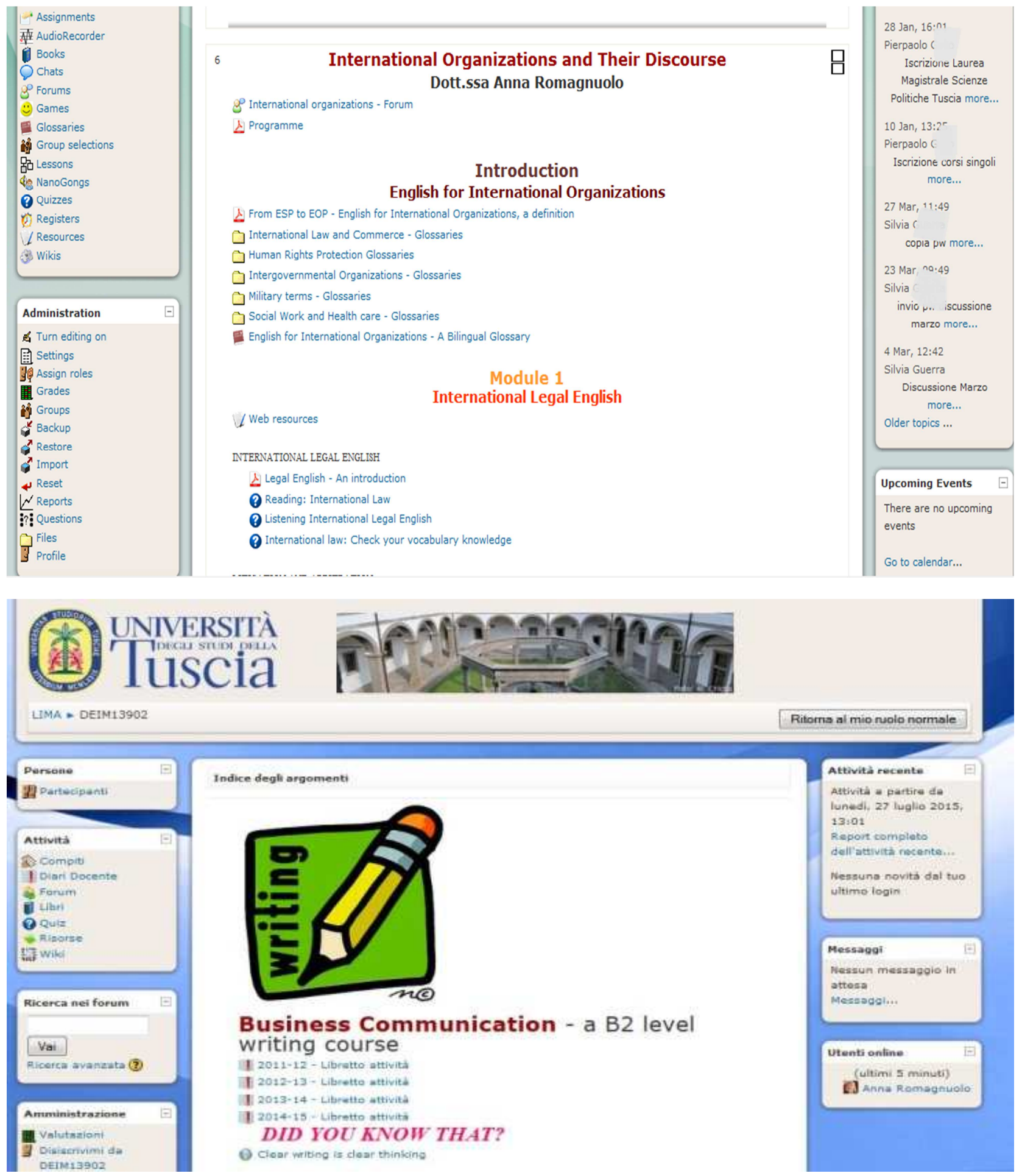

Figure 1. Moodle course screenshots. 
Any element within a Moodle course can be edited, thus making the main page customizable: themes can be changed, side blocks can be added, and file folders, graphs, photos, videos, recordings and external links can be uploaded in the center column. Platform access is secured and course ownership, copyrights, privacy, and grading are protected since to enter the course site, students first need to create a Moodle account and, if the course is password-protected, use an enrollment key for which the course administrator can set an expiration date.

Moodle provides a flexible and user-friendly set of asynchronous collaboration and learning tools, among which:

- Discussion forum - where students can reply to instructors' posts or initiate their own

- Chat rooms - with interaction limited to texting

- Files folders to upload/download

- Assignment submission with the possibility for students of uploading a formatted file (Word, Excel, PowerPoint or writing online into the blank page provided by the assignment box.

- Instant messages to contacts who are currently online

- Online calendar to set events

- Online news and announcements

- Online quizzes and questions (Matching, Embedded Answers, Multiple Choice, Short Answer, Numerical, Random Short-Answer Matching, True/False)

- Workshops for peer review

- Wiki for collaborative work and group assignment

- Glossaries

Moodle allows constant monitoring of students' participation in online activities through individual automatic log reports that contain information about the type of work completed and the amount of time spent on each task by each student. The exercises students can complete in a Moodle environment can be automatically marked by the system if they have been designed as a quiz (close, multiple choice, drag and drop or True/False questionnaire) or can be graded manually by the instructor when designed as an online text. Grades and feedback are stored in the Moodle gradebook, which students can access anywhere and anytime by clicking on the "Grades" link located on the course main page.

Besides posting on bulletin boards (forums) and sending instant messaging, both students and teachers are given the possibility of uploading files, which makes Moodle an ideal tool in teaching writing online. Not only does the system allow instructor to set a timeframe for completing activities and submitting assignments, but it also allows him/her to permit progressive submissions of the same paper (an initial draft and a final draft) to provide progress feedback and better understand students' needs and improvements [10].

\subsection{Course Organization}

Information about the course goals, objectives and expected learning outcomes is conveyed through multiple means: an Introduction, a Syllabus and the Guidelines, which are also repeated in the Course Policy Section and briefly summarized in a "Welcome Message" sent to the online Forum every year (Fig.2-3).

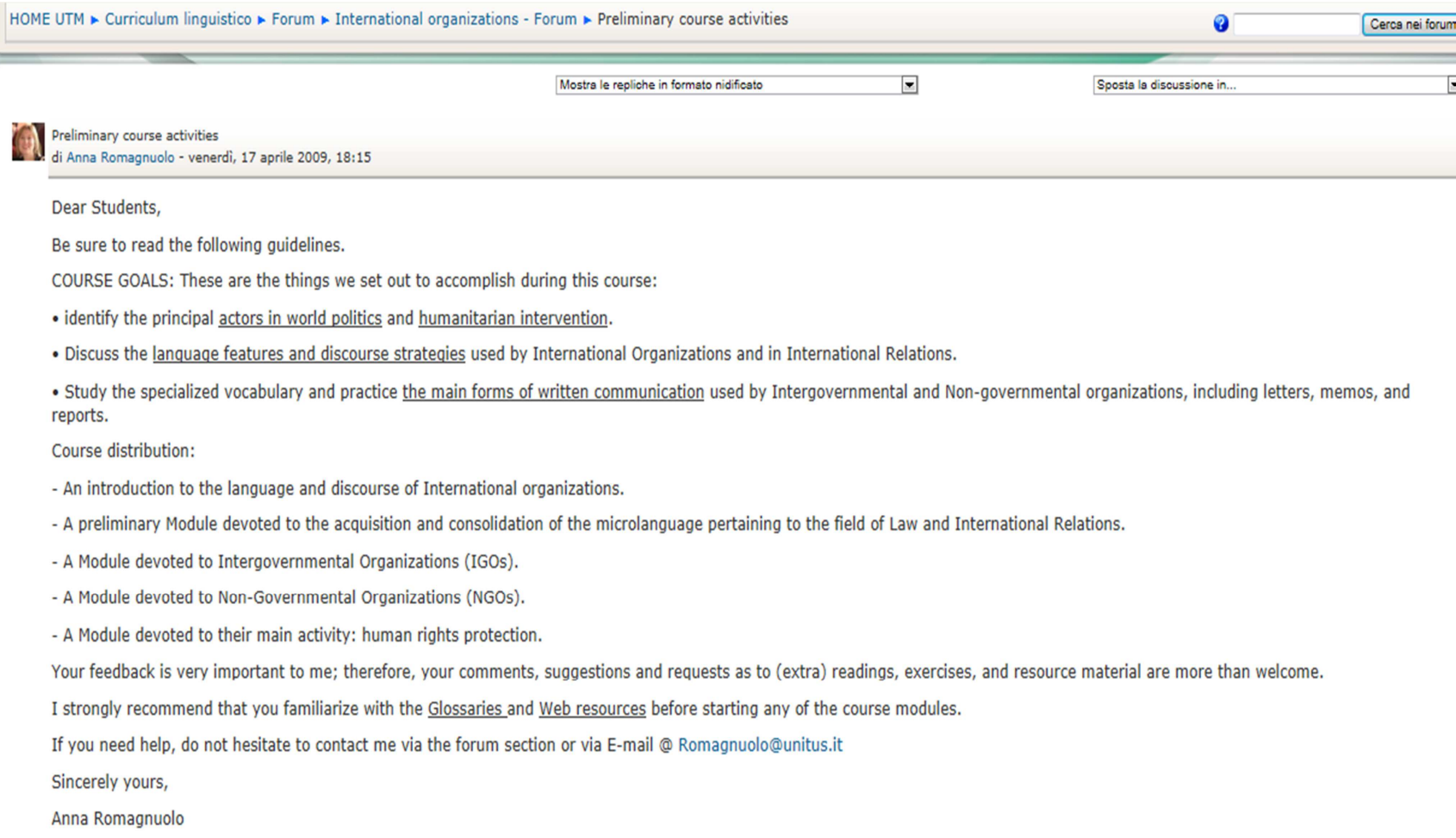

Figure 2. Welcoming message to the course of English for International Organization. 
Welcome to New Students!

di Anna Romagnuolo - martedi, 3 marzo 2015, 18:17

Dear Students,

Welcome to this year Business Communication course with a special focus on Business Writing. The course is delivered in a blended learning modality $=\mathrm{e}-$ learning + face-to-face meetings. Attendance is not compulsory but highly recommended.

I hope you will attend at least the initial meetings (especially if you are not familiar with the use of this e-learning platform) and that you will devote enough time to your assignments as soon as they are available.

Writing well is important in any language you use - as the Romans used to say, "VERBA VOLANT AND SCRIPTA MANENT". It is even more important in Business Organizations because it can save time and money, Good Bus Writing skills can help you land a job, earn you a promotion and, if this is your last exam, get you a degree.

If you study with diligence and use this platform regularly, you will improve your (English) writing skills and get good results at your final test.

Please make sure to read the Course Description file and the instructions pertaining to the online exercises, which have been abridged here:

The icons with a question mark indicate online exercises which will be automatically corrected by the Moodle platform and which must be completed before takina the exam; the icons with a small

As to the online writing exercises, corrections in red indicate grammar, syntax, vocabulary and layout mistakes; corrections in blue indicate necessary improvements; comments in pink contain your teacher's remarks and/or suggestions. Highlighted and underlined parts pinpoint relevant elements that need revision and/or attention.

Please feel free to suggest topics and exercises and ask questions that are relevant to the course.

I hope yo will enjoy it.

AR

Modifica | Cancella | Rispondi

Figure 3. Welcoming Message to the course of Business Communication.

Students begin by practicing reading skills and learning the microlanguage through multiple choice or True/False reading comprehension tests, and vocabulary crossword puzzles, fillin, and short answer quizzes; then, they study the textual structure and the rhetorical patterns (through sentence reordering and drag-and drop exercises) that may be useful to complete subsequent writing tasks, which go from paragraph writing to paragraph rearrangement and reformulation, from summary to critique writing, from the identification of the communicative purpose of sample letters to the composition of basic professional emails and memos, and then move further to more complex tasks such as writing fund- raising letters, petitions, reports on hot issues and critiques on assigned reading passages. Students' direct interaction (and participation in writing activities) is stimulated by forum discussions, bilingual specialized glossary composition and wiki contributions. The final assignment includes a brief commentary on the genre, language features and efficacy of a specialist text similar to those encountered in the reading and writing exercises. Helpful writing tips and resources are provided not only in posted lectures, notes, style guidelines and writing samples, but also through links to external webpages such as online dictionaries, terminology databases, corpora and concordancers. In both courses, organization is content-driven and grammar inputs are always field-specific, covering topics that are relevant to the ESP field (transitional words and phrases, indirect speech, narrative tenses).

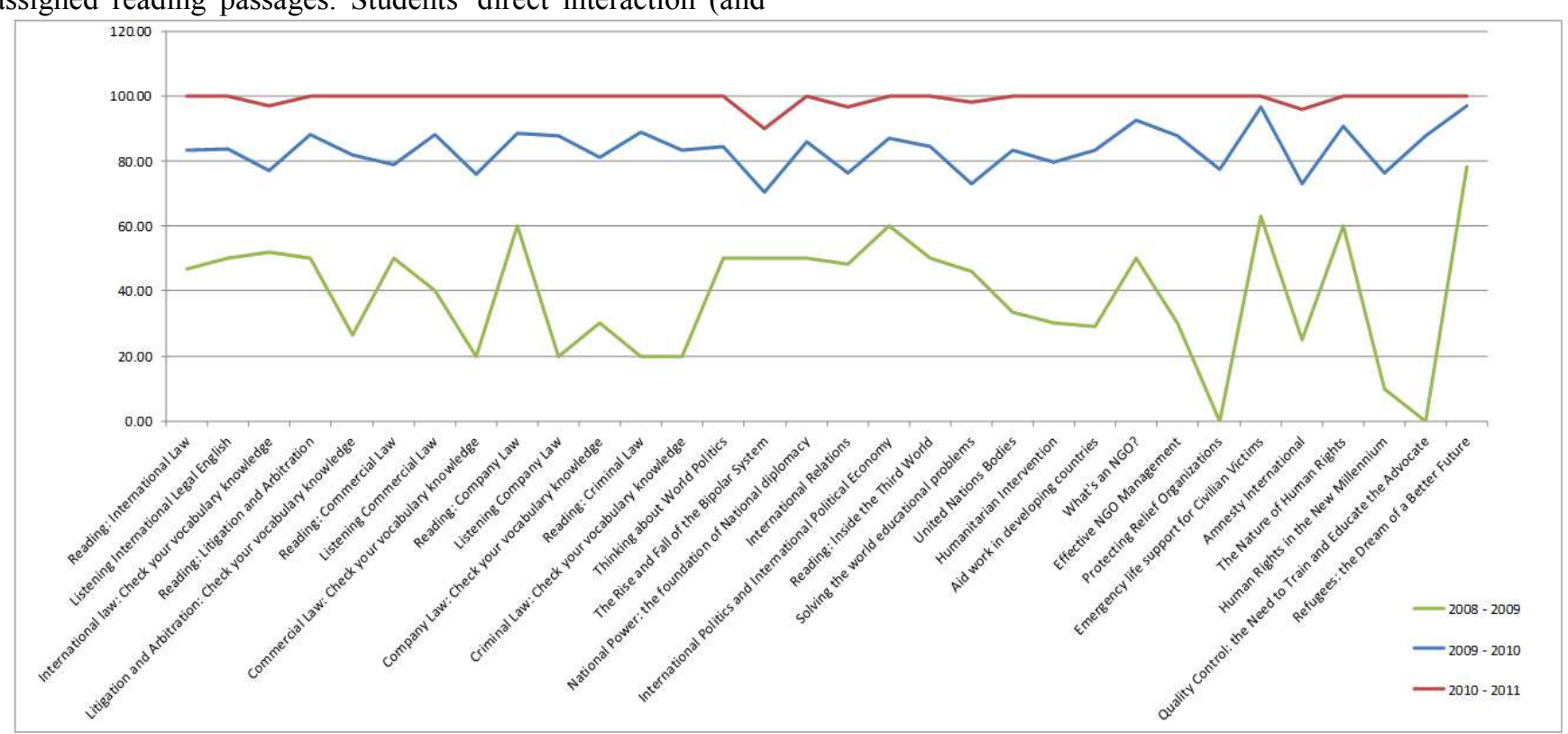

Figure 4. Comparative grade range in the years 2008-2011. 


\section{Findings}

After some initial discomfort with the electronic tools used in the course and the unfamiliar tasks of collaborative writing, students adapted enthusiastically to the contentbased and learner-centered nature of the course. What they have appreciated most is the dialogical and practical approach, congruent with the vocational emphasis of both courses, aiming at stimulating critical reflection and the use of the platform for a number of authentic purposes, such as writing in role play exercises and seeking information from specialized sites and repositories.

Figure 4 shows the average and comparative results of students' writing assignments in the three academic years the Master course was offered.

Outcome improvement can surely be credited to better course organization, simplification of online technical instructions and provision of specific policies concerning accountability for required work and academic honesty. The implementation of a plugged-in anti-plagiarism software and the dissemination of the course guidelines through forums, the placement of specific directions on each lesson page and the uploading of a FMM (Frequently Made Mistake) document have also contributed to it. As C. W. Pollard says, "Information is a source of learning. But unless it is organized, processed, and available to the right people in a format for decision making, it is a burden, not a benefit" [11].

\subsection{Online Course Pros}

Participants can access, select and retrieve course material and messages at any time and from anywhere as long as the course is hosted on the University server. The same is true of grades and corrections which can be stored to track students' engagement, made accessible to the learners, and archived at the end of the course. Corrected papers can be stored forever for the benefits of Alumni, who can be granted uninterrupted access to the platform, and of teachers who can use this data repository to avoid giving inconsistent, idiosyncratic and incomplete feedback, to track students' improvements and decide when to amend or integrate course material (Figure 5 shows students' comparative performance in the assignments of the first few weeks of this year course of Business Communication) and create a database of recurrent mistakes, which, in the long run, can become an ever-increasing learner corpus [12] usable to study language acquisition and inform syllabus design.

Online writing classes help students develop writing (and computer and internet) skills in ways traditional classes cannot. Language practice and writing exercise are not limited to assigned tasks, to group activities and solicited forum or chat discussions. Writing is simply unavoidable with online interaction: distance learning (language) students need to write if they want to ask questions, join groups and communicate with colleagues. Therefore, throughout the course they encounter numerous examples of language in practice: they can not only ask questions but also read and study other students' questions and the responses given to these questions in public forums, or they can write themselves the answers; they can share information, advice and recommendations (see Fig. 6).

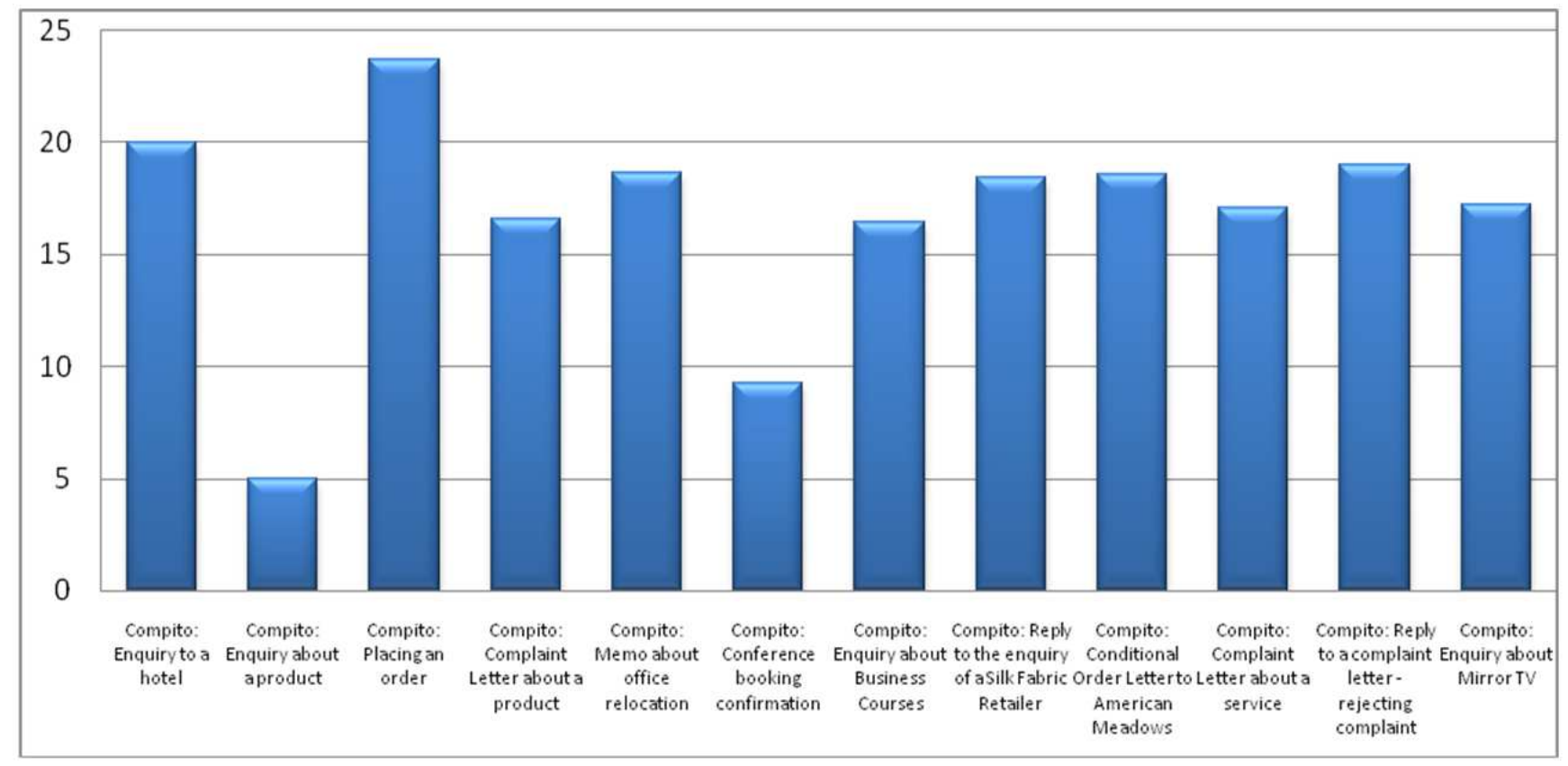

Figure 5. Grade comparative survey for the Business Communication course. 
Re: Test "Listening International Legal English"

by Ugo - Friday, 15 May 2009, 05:39 PM

Hello

thanks for the quick answer.

Definitely we don't wanna be too picky, it was just for my understanding. Anyway your question regarding the difference between citizenship and nationality is not so easy since, apparently, a concrete difference does not exist. According to a small research I did, citizenship is a "law" term and implies rights and duties; nationality is more a "social" term and implies the sense of belonging to a Nation in the meaning of language, culture, traditions, religion, basically what is distinctive in a people history.

Generraly speaking you can change your citizenship or get a double one, but usually you don' t change your nationality.

Regards

Show parent | Edit | Split | Delete | Reply

Re: Test "Listening International Legal English"

by Anna Romagnuolo - Friday, 15 May 2009, 08:46 PM

Very good reply. Although, the dictionary of Government and politics does not differentiate between the two terms by stating that "nationality" is "the condition of being the citizen of a state", the handbook of International Politics (that you can find in the references) defines "nationalities" as cultural entities.

Figure 6. Example of student-teacher interaction in the course of English for International Organization.

Online (writing) classes when successfully managed, so as to guarantee supportive collaboration and active participation of all members, can also develop honest criticism [13] and social and cross-cultural communication skills as proved by several studies [14- 16]. As it has been observed, online students create a community of practice [17] that reproduces real-life workplace interactions and learning experiences.

In blended courses, once students' permission has been obtained, corrections can be shown to the entire class by using an OHP so that everybody can learn from each other's mistakes and participate in collective reformulation.
However, self-editing and peer correction exercises can also be conducted entirely online via group and workshop assignment, by starting a wiki or simply by allowing multiple and subsequent submissions of the same paper.

\subsection{Online Course Cons}

Lack of basic computer skills may be an issue. Some students may need (and indeed needed) to be taught how to use technology (Fig.7).

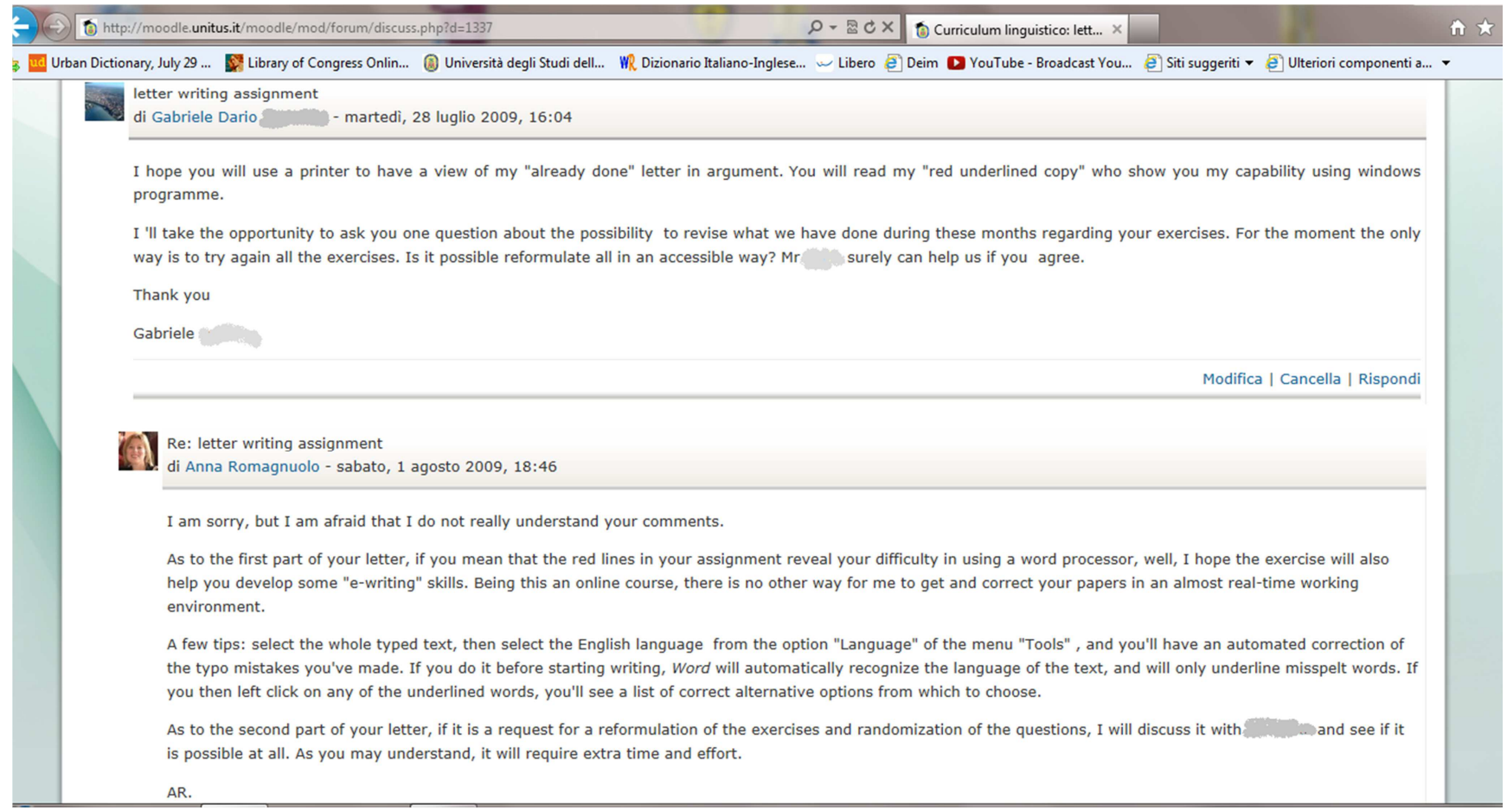

Figure 7. A student's uneasiness with e-writing.

Word formatting is not recognized by the Moodle html editor and the layout of documents written with Word is cancelled when copied and pasted in the Moodle online text assignment space. Therefore, written assignments and corrections need to be uploaded as separate word files (if students want to save their work layout or if the teacher 
wants to use Word edit tools). Otherwise composition and correction need to be completed directly in Moodle, which may cause data loss in cases of unstable internet connection.

Moodle access can freeze if users attempt to exceed file upload limits or if too many users try to log in at the same time, in which case those who are already online may be compelled to reboot, log back in and reload their work. The same problem occurs if the instructor spends too much time on online manual corrections which may be deleted if the software crashes or freezes. A backup file is always necessary

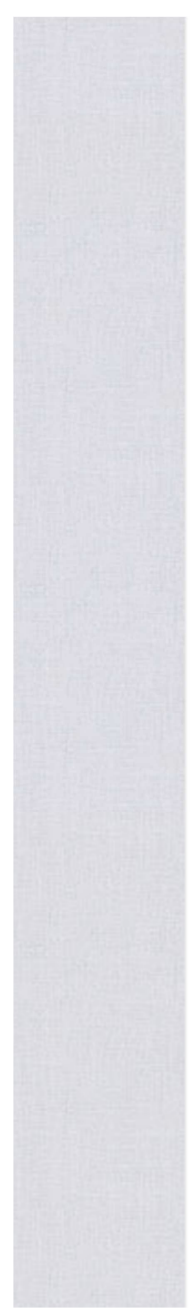

\section{Grade}

\section{Grade}

with online work.

Plagiarism has always been an issue in writing classes and can be even more so in an online writing course if students decide to share corrections - in crowded courses, such as mine, teachers can be tempted to start correcting as soon as the first piece of homework is uploaded. Moodle 1.9 version, which was used for the Master course would not keep teacher's feedback hidden until the correction process was completed. Fortunately, the new version, Moodle 2.9, provides several grading display options (Fig. 8).

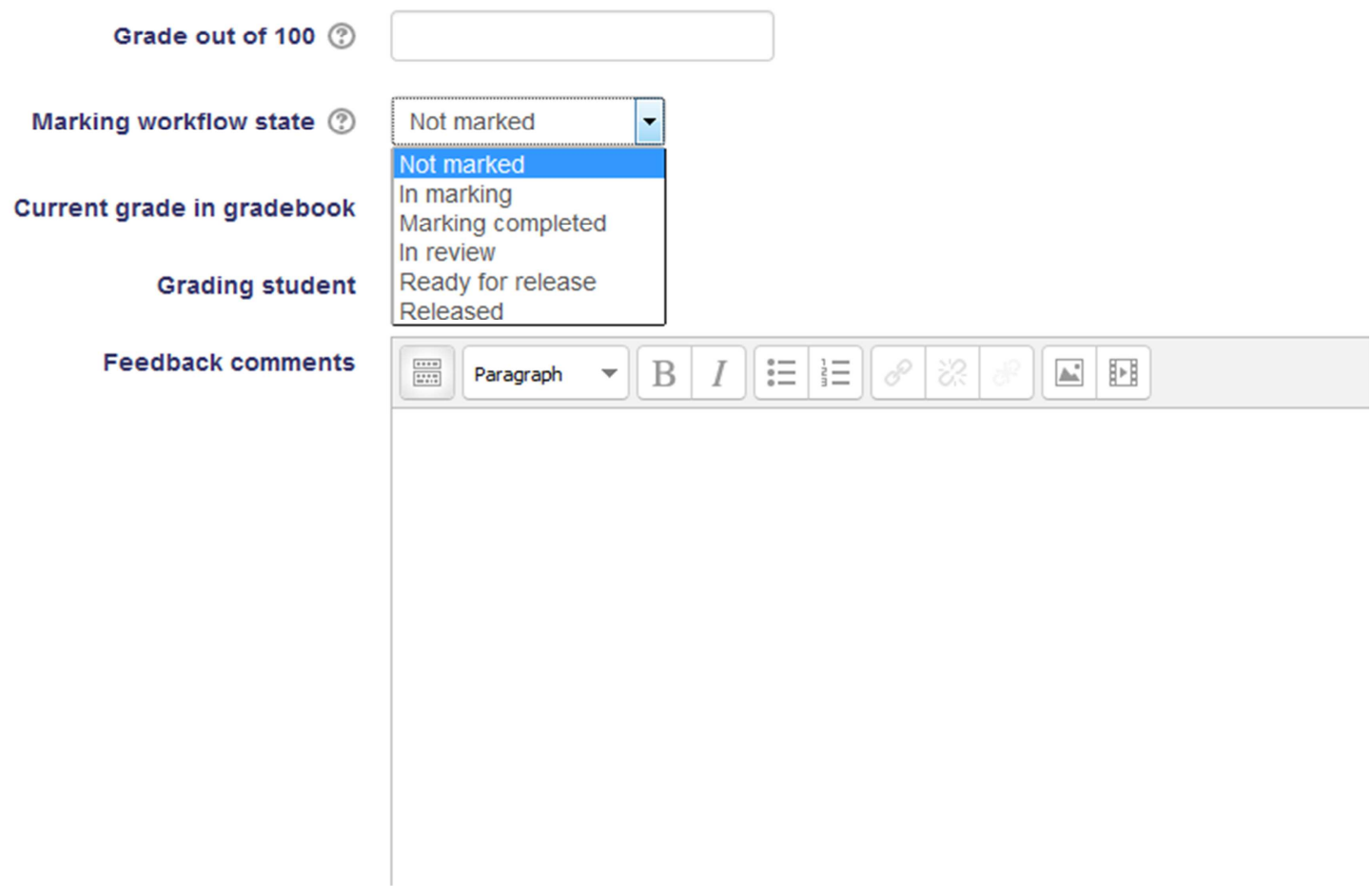

Figure 8. Moodle grading release options.

\section{Error Correction and Analysis}

Error correction has been "conservative", aiming at preserving as much as possible of the original text and, therefore, more focused on global than on local errors. Teacher feedback has been mostly direct: no error symbols or abbreviations have been used in corrections because of students' proved uneasiness with cryptic error codes [18], and verbal clues (such as wrong word order, wrong tense) have only been used when known to students; genre and resister errors have been pinpointed by using highlighting and underlining and occasional in-text response and final comments have been inserted to stimulate revision and provide advice. Grades have been assigned by following the common BEC and IELTS writing marking scheme which suggest assessing task achievement, textual coherence and cohesion, lexical richness and grammatical accuracy. Importance has also been given, especially in the Bus. Com. course, to students' choice of the right textual format, appropriate register, and mastery of other text-linguistic standards such as informativity, intentionality and acceptability.

A preliminary survey of the most frequent mistakes made by both students of Eng4Int. Orgs and Bus. Com. courses has revealed that errors are field independent - in other words, even if specialist vocabulary close exercises are usually 
perceived by students as the most difficult, most mistakes are not lexical and are equally frequent in commentaries on ECHR decisions and turnover reports, in advocacy letters and reminders of payment. They are mainly due to unconsolidated basic grammar and syntax, lack of pragmatic competence and poor knowledge of the job-related communication conventions.

Of course, spelling mistakes are numerous and capitalization mistakes too, but they are likely to be caused by texting and social network writing habits. On the contrary, tense mistakes, subject/verb missing agreement and a marked preference for post-modification, rather than for premodification, are often attributable to L1 interference. The transcription of two assigned tasks and three extracts from students' writing samples of both courses, shown in Figure 9, will illustrate these points (correction color choice is explained in Fig. 3).

Eng4Int Orgs Commentary Writing Task Insoruction 1:

Read the passage abridged from John G. Stoessinger's book Why Nations go to $\mathrm{Kar}$ ? and the file "How to write a crit ical review or commentary". Then write a onepage critique ( $\max 400$ words) on the reading.

somple la

I agree about with what I read from "Why nations go to war". I agree that in mact of the times the A war often stans stems from a misperception of the reality. This has happened a lot of time in our recent history and despit this, I have the feeling that, (Too colloguialy unforavate \&. it could migit happen again. Revise modals)

somple $2 a$

According to the author $J$. Stoessinger it seems that the main caus of a war is the a leader's mipereption of his/her actersan's power I cannot believe this expe rience d author beigg is so rechuctive on such a big serious issue. In the first sentence : "a leaders misper eption of adversay"s power is periaps bhe reason for nations to go to war". where the acterb "perhaps" gives me the fee libg that even tie author is not comple tely convix ed of his own stateme nt: he doesn't

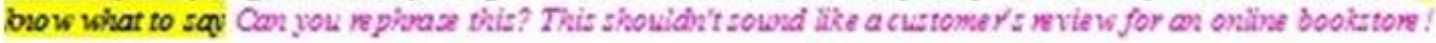

sanple $3 a$

The author brings in some relevant examples of wars which axc anding to hin, did bre at out bec ause of different tipes of misperceptions. According to the author, if the leaders of the various nations involved in a war whent had viewed reality rather than their own distorted represeneations, it may would have been posstble they would have been able to avoid conflicts asd wars on a massive $x$ ale or and evento avoid war aitogether (Revise if-clauses)

The other statement made by the outhor is that a war is the best c we for war (A re you realily swe that he did say thar?) Not even close. (200 colioguial) I thought that after bie II WW Holocaust bee would never be concentration camps of concentration again

Bus. Com. Report Writing Task Instruction 1:

The company you wodk for is having problems with Sorenson, one of its suppliers. Your line manager has asked you to write a report giving details and recommending a sobtion. Look at the information below [...], and then write your seport (250-300 words).

somple paper 16

Dear Sir This showidit be a lersy but as isformathe neport ll! after comparating comparing the estimate of ow supplier, I an dissatiffled of with the work of Sorenson Sorenson's

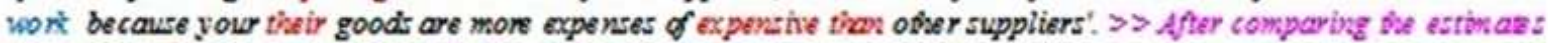
of all our supplier. Ic an tell bat Sonenson's prices as the mostexpensthe.

sample paper 26

REPORT TITE: "Sorenson's problems" Probiems with Soreston/Supplier Evaiwation

OBJECT SUBJECT. "Report of on the situation and possible siutions"

The have had some problems with one of our suppliers, Soreson about as to delieries product quality and iboires. The most important serious problem is the late de liveries consgument; therefore, we have to ask Sorenson to improve his de invery system.

An other A nobser problem is this wsatiffax tion of the customers's diszatisfaction with the (quality of the) srvice, which is not good adequaz and this makes a bad can danage the image of four our company. [...] sample paper $3 b$

Dear.Mr. Sorenson Zu showlds't be writbeg to Mr Sorenzon but to your bouz who azsigned you a report!

Th are very disappoint d with your service: you have been deitiering delitered late and poor quality goods of bad

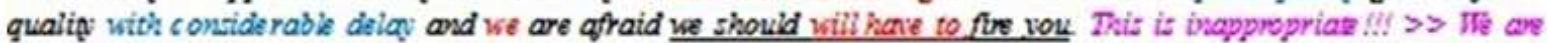
gfraid we will have to change supplier.

Figure 9. Students' writing samples.

Not only do these text portions reveal the predictable interference of the mother tongue grammar on the choice of the preposition accompanying the verb ("agree about", "dissatisfied of"), the selection of the tense sequence ("This happened a lot of times", "you delivered late") and the confusion of modal verbs ("it could happen again", "it may would have been possible"), but they also show a limited repertoire of advanced vocabulary, especially regarding collocations (with the overuse of antonym adjectives such as good and bad and frequent word repetitions) and the lack of communicative skills required for workplace interactions, confirming the results of recent studies on L2 acquisition 
[19-20]. In particular, sample papers $1 \mathrm{~b}$ and $3 \mathrm{~b}$ demonstrate how hard it is for students to use professional textual genres that have not been practiced in their L1 and to acquire jobrelated pragmatic awareness when the working environment is unknown (clearly, the student writer of sample $1 \mathrm{~b}$ is unaware of the implications of supplier-manufacturer relations).

\section{Conclusions}

Online courses can be rewarding and fulfilling not only for students but also for teachers, who can find in distance learning platforms a long lasting repository of their teaching material, the tangible evidence of correction marathons and experience-based advice for changing or improving course content and students' workload. Of course, online courses do not save much Institutional money nor teachers' time unless they have been carefully designed: objectives, policy (particularly on plagiarism and cheating) and minimum requirements for successful completion of each program need to be clearly stated in Course/Site Description at the very beginning, posted in a Guideline file or PowerPoint slide show, repeated in Syllabi, Forums and Messages, and constantly reminded in replies to students' emails concerning assessment. Also grading needs to be made explicit especially regarding online participation (contribution to discussions, glossaries, wikis) and prompt completion of the exercises. If the required participation is not explained or mentioned as being evaluated, the majority of students won't participate and disruptive ones will raise objections. If the course program includes summative tests, course contents and activities need to be sequenced so that students don't get lost or discouraged by negative automated feedback.

Constant feedback is important: students need to perceive a context of care and be encouraged to overcome fears and bias they may have toward off-the-shelf e-learning. Especially in writing courses corrective feedback is important, although it may not be sufficient when poor content and communicative inefficacy are determined by the lack of extra textual knowledge. In that case, though, additional reading and audio-visual resources can be added to the course webpage or merely recommended to needy students. As Rossett maintains [21], online learning has many promises, but it takes commitment and resources, and must be done right.

\section{Acknowledgements}

The author is thankful to the University Technical Support Staff and particularly to Simona Paris for retrieving and aggregating the Master course test results.

\section{References}

[1] S. Harrington, R. Rickly and Michael Day (Eds.), The Online Writing Classroom. Cresskill, N.J.: Hampton Press, 2000, p. 8.
[2] L. Ortega, "Interaction and attention to form in L2 text-based computer mediated communication," in Multiple Perspectives on Interaction, A. Mackey and C. Polio, Eds. New York: Routledge, 2009, pp. 226-253.

[3] M. Warschauer, "Computer-assisted language learning: An introduction", in Multimedia language teaching, S. Fotos, Ed. Tokyo, Japan: Logos International, 1996, pp. 3-10.

[4] M. Hamilton, Autonomy and Foreign Language Learning in a Virtual Learning Environment. New York: Bloomsbury Academy, 2013.

[5] J.W. Creswell, Educational research: Planning, Conducting, and Evaluating Quantitative and Qualitative Research. Upper Saddle River, NJ: Merrill Prentice Hall, 2002, p. 485.

[6] D. H. Hymes, "On communicative competence," in Sociolinguistics, J.B. Pride and J. Holmes, Eds. Harmondsworth, England: Penguin Books, 1972.

[7] J. M. Swales, Genre Analysis: English in Academic and Research Settings. Cambridge: Cambridge University Press, 1990.

[8] C. Berkenkotter and T. N. Huckin, Genre Knowledge in Disciplinary Communication: Cognition/Culture/Power. Hillsdale: Laurence Herlbaum, 1995.

[9] Cfr. Moodle Statistics. Retrieved July 20, 2015 from the site https://moodle.net/stats/.

[10] A detailed description of this free, open source Learning Management System and clear instructions for course designers can be found in W. H. Rice's manual, Moodle Teaching Techniques: Creative Ways to Use Moodle for Constructing Online Learning Solutions. Birmingham: Packt Publishing, 2007.

[11] C. W. Pollard, The Soul of the Firm. Grand Rapids, MI: Zondervan, 2000, p. 123.

[12] A small learner corpus has indeed been created with the business correspondence produced by the University students of the Bus. Com. course in the last few years. The corpus, manually annotated following the Louvain error tagging guidelines, will be available on the University webpage next year. A detailed description of the Corpus and initial Computer-aided Error Analysis of the collection of the Italian learners' writing samples can be found in A. Romagnuolo, "ItalBEC: An Italian Learner Corpus of Business English", unpublished.

[13] M. S. Marx, "Distant writers, distant critics, and close readings: Linking composition classes through a peercritiquing network," Computer and Composition, vol. 8 (1), pp. 23-39, November 1990, retrieved March 2012 from http://computersandcomposition.candcblog.org/archives/v8/8_ 1_html/8_1_2_Marx.html.

[14] B. Davis, and R. Thiede, "Writing into change. Style shifting in asynchronous electronic discourse," in Network-based Teaching. Concepts and Practice, M. Warschaucher and R. Kern, Eds. Cambridge, UK: Cambridge University Press, 2000, pp. 87-120.

[15] L. L. Irvin, "The shared discourse of the networked computer classroom," in Trends and Issues in Post- secondary Studies, K. Austin, Ed. Urbana, IL: National Council of Teachers of English, 2000, pp. 219-228. 
[16] M. Warschaucher and R. Kern (Eds.), Network-based Teaching. Concepts and Practice. Cambridge, UK: Cambridge University Press, 2000.

[17] The expression is commonly credited to Jean Lave and Etienne Wenger who used it to describe apprenticeship experiences; in their later studies, it has became a synonym of communities of practitioners who share implicit, pre-acquired knowledge and, therefore, foster the production of new knowledge. Cfr.: J. Lave and E. Wenger, Situated Learning: Legitimate Peripheral Participation. Cambridge: Cambridge University Press, 1991.

[18] For an overview of the state of the art in written error correction research, see the numerous studies conducted by Dana R. Ferris on students' reactions to teacher corrective feedback and its effect, and, in particular, Treatment of Error in Second Language Student Writing, 2nd ed., Ann Arbor: The University of Michigan Press, 2013.

[19] E. M. Mestre Mestre and M. L. Carrió Pastor, "A pragmatic analysis of errors in University students' writing in English", English for Specific Purposes World, vol. 12, pp. 1-13, 2012.

[20] C. Pérez-Sabater and B. Montero-Fleta, "Pragmatic competence and social power awareness: the case of written and spoken discourse in non-native English environments", International Journal of English Studies, vol. 14, pp. 21-38, 2014.

[21] A. Rossett, "Waking In The Night And Thinking About ELearning," in The ASTD E-Learning Handbook, A. Rossett, Ed. New York: McGraw-Hill, pp. 3-18. 